\title{
NEW PROPHET VERSUS THE STATE A Study of the Phenomenon of New Religious Streams in Indonesia
}

\author{
By: Zuly Qodir**
}

\begin{abstract}
This paper elaborates a phenomenon of the new Prophet in Indonesia. The New prophet of community is left (separated/heretic) by Majlis Ulama Indonesia (MUI) because such community is considered to perform heresy in religious mainstream (Islam). Why does this grow? What is simultaneous aspect within social ills, such as state failure in managing plurality in Indonesia, or is that connected with religious mission (Dakwah) in this contemporary phenomenon?

This paper introduces state failure on dakwah/mission in Islam, pluralism management, and destructed national politics and economic growth. In this paper I describe mass destructive on sect (heresy) community by MUI. This paper presents religious sociological perspective as religion is looked as a social reality, not as religious dogma and state preposition. The New Prophet is at a diametrical position to the state (new prophet vis a vis state).

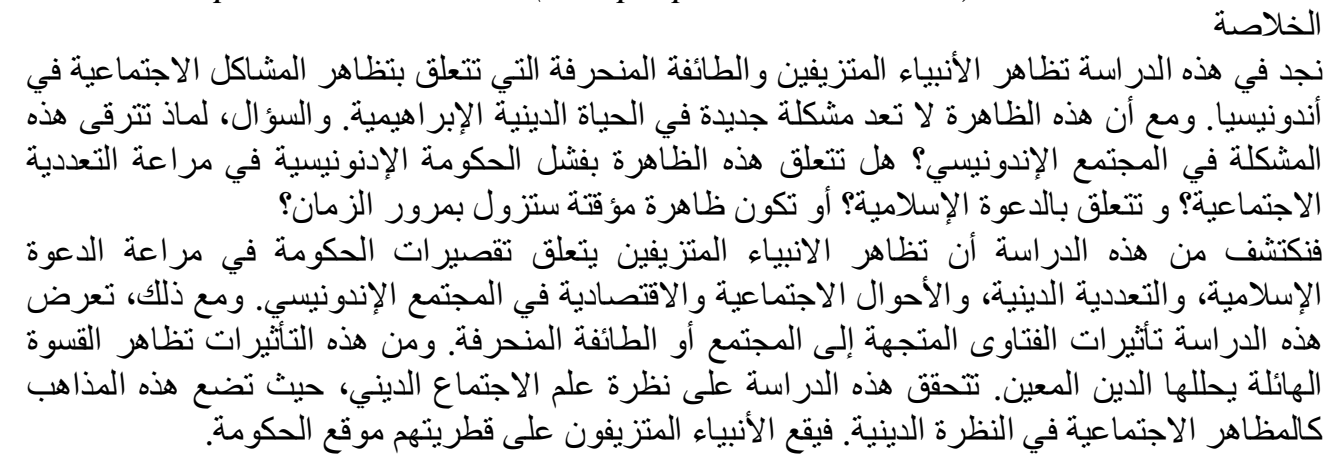

Keywords: new prophet, heresy, state, MUI

\section{A. Introduction}

It is interesting to further investigate why new Islamic communities emerged? Is that really a new phenomenon which occurred in the reformation era? We know that before the reformation there had been no "aliran-aliran" (religious sects, communities, or groups) which MUI (Majelis Ulama Indonesia) denounced as "deviated" (sesat). This is strange since these "aliran-aliran" such as AlQiyadah Islamiyah, Lembaga Dakwah Islam Indonesia (LDII) and the Ahmadiyah in fact emerged before the reformation era. Another interesting is the fact that

\footnotetext{
${ }^{*}$ Researcher of Religion and Social Issues
} 
these "deviated" communities attracted the quite significant number of members. Al-Qiyadah Islamiyah which was declared as being "deviated" by the MUI in October 2007 has 4.500 members in Yogyakarta. In addition to the middle class society, most of them are university students and other educated people. This fact seems to affirm what Mansour once observed ${ }^{1}$ that Yogyakarta is a good place for diverse alirans from the right to the left wings, from the opportunists to the radicals.

Some people see the reformation order as the "free" (serba boleh) order. Religious organisations, communities and political parties banned in the New Order have re-emerged in this era. In the New Order, there were only three political parties, a political system which Arbi Sanit (a political observer) ever called monolithic with a single majority (Golkar). The reversal took place in the reformation order in which the number of political parties were 48 in 1999 election and 24 in 2004. In addition to political parties, many new social and religious communities appeared. This was perhaps what Simon Philpott called "blessing" of democracy or even that of civil society for Indonesian people. This was also part of the influence of the wave of democratization went on in the Philippines, Korea, Venezuela, Republic of Czech, or in Islamic countries such as Iran, Malaysia and Egypt. ${ }^{2}$

This article deals specifically with the religious communities the MUI considered 'deviated'. I will take the perspective of sociology of religion. Therefore, this article places religion in its sociological context, or religion as social reality. In this regard, I follow Emile Durkheim who sees religion as a social phenomenon in society. Religion has belief systems, rites, gatherings, sacred books and leaders. ${ }^{3}$ Even though Durkheim's thesis was formulated more than 20 years ago, it nevertheless is relevant to analyze current phenomenon in Indonesia. Related to the new religious movements, this article follows Eileen

\footnotetext{
${ }^{1}$ Mansour Fakih, Jalan Lurus: Manifesto Cendekiawan Organik (Yogyakarta: Pustaka Pelajar-Insist, 2004), p. 41.

${ }^{2}$ Simon Philpott, Meruntuhkan Indonesia: Transisi Politik Indonesia, translated from English by Uzair Fauzan (Yogyakarta: LKiS, 2001), p. 78.

${ }^{3}$ Emile Durkheim, The Elementary Forms of the Religious Life (New York: The Free Press, 1965), p. 274.
} 
Barker $^{4}$ who has analysed the roots of the rise of religious movements in Christianity for Muslim community in Indonesia.

In the contexts of Christianity and Islam, a number of scholars such as Azumardy Azra, Hendro Prasetyo, Franz Magnis Suseno, SJ, and Th. Sumartana have discussed about the new religious movements and their connection with religious fundamentalism and violence in Indonesia after the national economic crisis $1996 .{ }^{5}$ Th Sumartana and Ahmad Suaedy have dealt with religious violence in Situbondo. This study concludes that there was a missing link between pesantren leaders (kiai) in Situbondo and mass violence which led to brutalities such as burning houses, killing people and destroying churches and other public facilities. ${ }^{6}$ Loekman Soetrisno and others at Pusat Studi Kawasan dan Pedesaan Universitas Gadjah Mada (2007) have studied social conflicts. Uproars in Sanggauledo and Sambas, West Kalimantan and in Ambon, Moluccas have been studied by Komnas HAM $2000 .^{7}$

The emergence of new prophets in Indonesia has similar characteristics with that in other countries, regardless of their different details. As part of the new religious and social movements, the appearance of the new prophets is intimately related to the internal problems of a religious community, socio-politics and the like. In view of these characteristics, we may use the previous perspectives in this discussion. However, it should be kept in mind that in this article I do not pretend to answer the complex problems facing religious societies. Instead, I hope that I can make a fruitful contribution to the discussion.

\section{B. The Reasons for the Emergence of New Prophets}

The emergence of new religious communities has been often considered to have social, cultural and economic backgrounds. In addition, the idea of the

\footnotetext{
${ }^{4}$ Eileen Barker, New Religious Movement: A Practical Introduction (Portugal: HMSO Publishing, 1991), pp. 75-84.

${ }^{5}$ Tarmizi Taher, Radikalisme Agama (Jakarta: PPIM-IAIN, 1998), pp. 32-42.

6 Th. Sumartana and Ahmad Suaedy, Kerusuhan Situbondo (Yogyakarta: Laporan Penelitian, Interfidei, 1997), pp. 25-30.

${ }^{7}$ Wahyu W Basyir, dkk., Konflik Sosial Sanggalauledo (Jakarta:Laporan Penelitian, Komnas HAM, 1998), pp. 78-80.
} 
Messiah who will save humankind is related to the subject under discussion. Gregory Baum has signalled that new religious communities emerged from alienation within certain religious communities. In such a condition they needed a new guidance as well as a saviour figure. This is a Messiah tradition in Christianity. ${ }^{8}$ Bryan Wilson maintains that they appeared in an "official" religious tradition as a response to social problems such as the deterioration of economy, politic, exemplary figures and the hope of a saviour. In such a condition a saviour who comes with liberating promises and new ways will attract people to follow. This is a religious Millenarianism. ${ }^{9}$

Apart from the aforementioned reasons, the emergence of new religions or new prophets in a religious tradition is inescapable from contestations of authority in interpreting religion, exerting social control, and maintaining a religious tradition from being "falsified" and "deviated" from a mainstream point of view. This is what Meredith Mc. Guice has called competition for authority sources, including religious legitimacy. ${ }^{10}$

Based on the sociological explanation above, we can further analyse Muslim communities declared by the MUI of being deviated. The MUI is only of the religious authorities in Indonesia who compete with each other. The question is what if fatwas of the MUI are not obeyed by Muslim societies. This can delegitimate such respected organisations as the MUI.

The MUI and other religious organisations are competing with each other regardless of being representative of Indonesian Muslims. The MUI might claim that it comprises prominent Muslim scholars who may not do wrong in issuing fatwas. It is to note however that like the MUI, other religious organisations do issue the similar fatwas which might contradict. This is the problem of rational and affirmative authority over the power. As a semi-official state organization, the MUI seem to affirm its authority by issuing fatwas to be legalised by the state.

\footnotetext{
${ }^{8}$ Gregory Baum, Religion and Alienation: A Theological Reading of Sociology (1975), pp. 227-238.

9 Bryan R. Wilson, Magic and The Millenium: A Sociological Study of Religious Movements of protest Among Tribal and Third World Peoples (1973), pp. 309-314.

${ }^{10}$ Meredith B McGuice, Religion: The Social Context (1981), pp. 183-185.
} 
The question is why the MUI issued a fatwa for a certain "presumed" deviated Islamic community and not for others who opposed or supported the MUI? Is this not a latent power game and competition? And who has the right to set criteria of deviation of certain communities? Is it that the MUI is composed of persons, not of divine Angles or Prophets representing God?

Khaled Abou el Fadl, expert in Islamic law at the University of California Los Angeles (UCLA), maintains that religious authority should be on the hands of specialists in Islamic law, economic, politic, or culture. However, religious authority often leads to the religious authoritarianism. This is because the bearers of religious authority frequently function not as experts but to legitimise a political power by supporting status quo. Religious authority then disappears and no one knows who actually has the right. ${ }^{11}$ In view of the uncertainty of the bearers of religious authority, condemnation of certain religious communities and individuals becomes socially and politically problematic. Even authoritative organisations like the MUI are frequently behind the state power. The MUI in this regard faces two serious problems: that of self-authority and the authority of the state. Negative reactions tend to be unavoidable.

Taking all this into consideration, the emergence of new prophets compels us to conclude that this is not a novel problem, especially in the tradition of Abrahamic religions. They have emerged in every of bad social, economic, politic and cultural conditions. Endless debates on who are the minority and who are the majority make the problem deteriorated and lead to the emergence of new prophets and religious communities. In such conditions, it can be said that a new prophet is a reformist, a rebel against status quo. New prophets often feel inconvenient with every establishment and homogeneity. By seeing the new prophets as reformists who appose status quo, there should be no social, political, theological or even sociological problems. The problem comes up when they are seen from the conventional perspective that there is no a prophet after Muhammad.

\footnotetext{
${ }^{11}$ Khaled Abou el Fadl, Atas Nama Tuhan, translation (Jakarta: Serambi, 2004), pp. 304312.
} 
This must be the concern of religious and political elites in such a way that they do not easily condemn communities different from the mainstream of being deviated. At the same time they pay less attention to social, religious and political problems facing the country. It is true that it is easy to declare certain religious communities as being getting astray and put them into "order." However, the question is: can all groups different from or opposite to mainstream be considered being deviants and must they be put into order? Does the "order" mean the same as the extinction of them? What about remote communities that anthropologists and sociologists prefer to call indigenous people who believe in animism and dynamism? Should they be destroyed? But who have determined the criteria for dynamists and animists? Is it not that the criteria were set up by the adherents of Abrahamic religions or even by Muslims only? As we know, the terms revealed and worldly religions were coined by Muslims to distinguish themselves from the others. To further discuss this issue, I will focus on the cases of Ahmadiyah and Al Qiyadah Islamiyah which were declared by the MUI as deviant groups and led to social violence.

\section{Fatwa That Caused Public Anarchy}

The cases of the Ahmadiyah and Al Qiyadah Al Islamiyah have been controversial groups in current Indonesia's religious life. The Ahmadiyah is the most everlastingly debated for this group has existed since the 1950-s. In addition to that, it was a legitimated group since its first establishment in Indonesia. Since the issuance of MUI's fatwa, the Ahmadiyah in Indonesia has become a target of condemnation. The contribution of its members since the formation of this country till the present has never been reckoned. This is an irony since the fatwa eventually has triggered endless violence to them. Some Muslims viewed the fatwa as having 'allowed' (menghalalkan) the violence. Even though the MUI rejected by stating that there should have been no violence, the fact told us the reversal. A series of violence suffering the members of the Jamaah Ahmadiyah in 
Kayumanis West Java, Kampus Al-Mubarok in Parung Bogor, in Mataram, Nusa Tenggara Barat is ample evidence for the anarchical consequences of the fatwa. ${ }^{12}$

The condemnation of religious communities poses a number of questions. First is that there are diverse opinions among Muslims as to who could be called deviated (or not deviated), and who has the right to make such a judgment. Is it that they who differ from the majority in rituals and believes could be named so? Is it better to say that we must respect our differences? The next question is whether the condemnation is part of discrimination over a certain group even when they really have followers, leaders, references and rituals in dealing with their religious practice. This is a serious problem for the MUI and its advocates who easily declare the others as being heretic. They seem to underrate structural, cultural and religious discriminations occurring in Indonesia. They pay less attention to the importance of creating the mutual respect among civilians, civil religion as a civil right, and a respected civic right.

Thirdly, the problem concerns whether it is possible for a religious institution to become a guardian for all religious groups. This is the urgent task of such religious institutions as the MUI more than only issuing fatwas which could lead to public violence, suspicion, and hatred, not only culturally but politically as well. The effect of such a fatwa issuance is even more destructive than the emergence of 'deviated' sects for it could easily trigger a wider anarchy. Apart from that, it will turn out to be a political and religious tribalism. In this respect, it is significant to understand why the MUI could more easily issue fatwas to the new communities much more than to the established religious institutions which claim to be the guardians of the umma (Muslim community)'s faith.

Concerning the fatwa on the Ahmadiyah, does the MUI have the bargaining position to prevent Muslim groups who did, and do, violence on the members of the Jamaah Ahmadiyah Indonesia (JAI)? Has the MUI informed to a wider public that in Indonesia, in addition to the Jamaah Ahmadiyah and the Gerakan Ahmadiyah, there are also other non-mainstream Muslim groups such as Shiah,

12 Ahmad Suaedy dkk., Poltisasi Agama dan Konflik Komunal (Jakarta: The Wahid Institute, 2007), pp. 49-76. 
the Naqshabandiyah Order, Shattariyah, Baghdadiyah, and Wahidiyah? Did the MUI give a fatwa to Front Pembela Islam (FPI), Majelis Mujahidin Indonesia (MMI), the Jamaah Ahlusunnah, and Hizbut Tahrir Indonesia which emerged after the demise of the New Order? These are a series of questions to the MUI.

Besides the emergence of new religious communities, the MUI also face what Akbar S Ahmed ever termed as the problem of religious commodification manifest in ritual commercialisations circulated through printed as well as electronic media and infotainments such as films, advertisements and TV programmes offering "spiritual materialisation". ${ }^{13}$ Such a spiritual materialisation is more dangerous for the initiators are actually not only exerting public deception but are taking financial benefits from what seemingly is considered religiously sacred. Has the MUI issued a fatwa on religious and mystery sinetrons? The Ahmadiyah, compared with sinetrons, is more constructive in the sense that it has contributed to the development of education by organizing elementary to secondary levels of education for the mass. Indonesian Muslims should be aware of the fact that the MUI could not control its fatwas, while at the same time the fatwas become public consumption. All are free to make sense of and interpret them. As a result, mass violence is often unavoidable.

Religious condemnation is a matter of understanding circulated in a heterogeneous society. No agreement concerning the Ahmadiyah is made. Some Muslims view the Ahmadiyah as being deviated, while others consider it as a Muslim group who deserves protection and the right to survive. The disagreement is also on Al Qiyadah Al Islamiyah, the Lia Eden community (Salamullah), and Yusman Roy (in the case of bilingual prayer). So, what would matter then?

\section{The State's Failure}

The appearance of new Islamic communities is the proof of the state's failure to manage diversity. Ted Robert Guur offers the thesis in Why Men Rebel that a power which is marginalised in a society for the reasons of political stability, economic gap, and cultural and access marginalisation will protest as a

\footnotetext{
${ }^{13}$ Akbar S Ahmed, Islam and The Postmodernism, (Toronto: MacMillan, 1998), hal. 73.
} 
hidden opposition. A civil community will oppose when the normal condition is unbearable and could not be tolerated. This is the root of civil rebellions in a country. ${ }^{14}$

As a plural country, Indonesia has diverse religious traditions, ethnics, and social groups. The state's failure to maintain this diversity will lead Indonesia to the loss of her national richness and strength. Moreover, the failure will cause political homogenisation and the scapegoat of certain communities for being not subjected to the will of the political regime. The state feels necessary to oppress for anticipating their potent danger. Nevertheless the state is not really aware that they will oppose some day.

The appearance of "condemned" communities in the context of social movement can be called protest movements by religious communities against the domination and authoritarianism of the state. Such movements exist not only in Indonesia but also in other countries. Many a religious movement become protest movements. Religious movements become one of the most influential elements of civil society in such countries as Brazil, Ecuador and the Philippines. ${ }^{15}$

The Ahmadiyah is the conspicuous victim of the state's failure to preserve plurality. The MUI not only condemned the Ahmadiyah but also those who campaigned for pluralism, secularism and liberalism. The MUI has served not only as the guardian of religion but as that of the state's status quo as well since this organisation is given the right by the state to issue fatwas on the 'deviated' communities.

The state's failure is not only related to the maintenance of plurality but also to the improving of people's prosperity. It has failed to create pro-poor-based policies so that until 2007 the number of the poor has increased up to 49, 5 million people according to the data issued by the World Bank (the data is different from the data by Badan Pusat Statistik (Central Statistic Bureau), that shows the decrease from 37 up to 17, 6 million in 2006).

\footnotetext{
${ }^{14}$ Ted Robert Guur, Why Men Rebel (Toronto: Mac Milan, 1992), p. 56.

${ }^{15}$ Lofland, Protes, trans. Roem Topatimasang (Yogyakarta: Insits Press, 2004), pp. 203225 .
} 
The complexity of social life and social conflict among social groups in a number of provinces in Indonesia is another proof of the state's failure. Since the New Order to 2006, Indonesia had become a place for bloody conflicts causing the extinction of many lives. UNDP (UNSFIR)'s data shows that until 2004 Indonesia was the country where the percentage of ethnic and religious conflicts was the highest. The high percentage was also of corruption. Transparency International Indonesia (TII) reported that until December 2007, Indonesia was the most corrupt country in Asia, and the fifth in the world. Forbes Asia Magazine, December 2007, reported the list of the richest Indonesian people of whom the least were state officials, while the most were the conglomerates close to the power centre. In the report, Abu Rizal Bakrie was the richest Indonesian.

In such a deteriorated social problem, people seem to lose their trust in the government. A number of observers such as Faisal Basri, Amien Rais, Abdurrahman Wahid, and Hidayat Nurwahid and Sutrisno Bachir stated that the state failed to establish poor-oriented policies, and to create democratic parties, to maintain religious pluralism. The state could not set up the harmonious relation of legislative and executive institutions, and even president and vice-president.

\section{E. The Failure of Islamic Promulgation}

In addition to the failure of the state, the emergence of new religious communities and new prophets was inseparable from the failure of Islamic promulgation (dakwah) either by organizations or individuals to enlighten Muslims. This is because the promulgation was to indoctrinate rather than to educate. Taking this into consideration, Islamic organisations such as the Muhammadiyah, the NU (Nahdlatul Ulama), and the like should be reinvigorated so as not to create political segregation which divides Muslim community (ummah). The segregation of Islamic politic is the result of Muslims' preoccupation with political affairs much more than with Islamic promulgation. Indonesian Islam has long witnessed the perplexed relation between political power and Islam as the religion of the majority. Consequently, Islamic attributes have caused inconvenience in Indonesian political life. This is one of the reasons 
of the failure of Islamic promulgation. People in turn could not distinguish clearly the voice of promulgation from that of politic. Both promulgation and politic become identical. Many a tawsiyah (religious admonition) by Muslim political elites bears Islamic symbols; even they do not really strive for the interest of ummah.

Such a condition has made Muslims perplexed in choosing ulama as a religious reference, while at the same time political elites often make use of dakwah as their political tool. The Muhammadiyah and the NU are faced with the internal problems such as the ineffective and inefficient management of organisation. Both organisations are even busied with their political movements. In such a condition, the ummah mistrust in them and could easily accuse other communities different from them of getting astray and deviated from "pure" Islam. Suspicion has become spread among them. They could not think rationally to face their problems. Have we ever thought that the uproars in Tasikmalaya West Java suffered the Rp 5 billion as the result of damages by certain Muslim groups that claimed to be the truest?

\section{F. Conclusion}

In the above discussion, as a matter of fact I would like to stress that the emergence of the condemned communities took place all of sudden but as the result of preceding processes. These processes could be politic, economic or religious. The state therefore must make a self-correction in serving its citizens, whether equality or discrimination it has made. In other words, has the state given an equal public space for all citizens in such a way that they have the equal right to express their aspiration without any discrimination? Otherwise, the state has made a politic of discrimination which contradicts the substantial democracy and the principles of public freedom.

Apart from that, we should think about how religious elites did participate in educating people. Did they use the elegant methods by providing free alternatives to them or one way and monolithic interpretation giving no room for dialog? As far as our topic is concerned, only God can make an ultimate judgment on 
whether certain religious communities have gone astray. Human can only interpret God's will and the absolute truth is on the hand of God only. Only by doing so can we, Muslims, be wise and think critically of any problems.

Commoners are often wiser in being religious than the elites. Their religiosity, however, is at times manipulated by the elites so that they become victim of the elites' religiosity which is symbolic. Therefore, they should not easily be involved in politicking religion.

\section{BIBLIOGRAPHY}

Aboue el Fadl, Khaled. .2004. Atas Nama Tuhan, Jakarta. Serambi.

Akbar, S Ahmed. 1998. Islam and the Postmodernism. Toronto: MacMillan.

Baum, Gregory. 1975. Religion and Alienation: A Theological Reading of Sociology. New York: Paulist Press.

B. Mc Guire, Meredith. 1981. Religion: The Social Context, California: Warsworth Publishing Company.

Barker, Eileen. 1991. New Religious Movement: A Practical Introduction. Portugal: HMSO Publishing.

W Wahyu Basyir. 1998. Konflik Sosial Sanggaledo. Jakarta: Komnas HAM, Research Report.

Durkheim, Emile. 1954. The Elementary Form of the Religious Life. New York.

Mansour Fakih. 2004. Jalan Lurus, Manifesto Cendekiawan Organik. Yogyakarta: Pustaka Pelajar-Insist.

Gurr, Ted Robert. 1992. Why Men Rebel. Toronto: Mac Milan.

Lofland. 2004. Protes, translated by Roem Topatimasang, Yogyakarta: Insist.

Philpott, Simon. 2001. Meruntuhkan Indonesi: Transisi Politik Indonesia, translated by Uzair Fauzan. Yogyakarta: LkiS.

Ahmad Suaedy et. al. 2007. Politisasi Agama dan Konflik Komunal. Jakarta: The Wahid Institute.

Tarmizi Taher et. al. 1997. Radikalisme Agama. Jakarta: Litbang Depag.

Th.Sumartana and Ahmad Suaedy. 1997. Kerusuhan Situbondo. Jakarta: Research Report, Interfidei.

Wilson, Bryan R. 1973. Magic and the Millennium: A Sociological Study of Religious Movement of Protest among Tribal and Third. New York: World People, Harper \& Row Publisher. 